\title{
自由表面を有する非圧縮粘性流れの数值解析 NUMERICAL ANALYSIS OF INCOMPRESSIBLE VISCOUS FLOWS WITH FREE SURFACE
}

\author{
西村敏雄*1, 近藤典夫*2, 加納充浩*3 \\ Toshio NISHIMURA, Norio KONDO and Mitsuhiro KANO
}

\begin{abstract}
The purpose of this paper is to calcurate imcompressible viscous flows with free surfaces by using the thirdorder upwind finite element scheme and the Arbitrary Lagrangian-Eulerian (ALE) method. Waves on the free surfaces are limited to the waves without braking conditions. Numerical dissipation added into the upwind finite element scheme is expressed by the fourth-differentials with respect to the flow velocities. The pressure is computed by the Poisson equation which is derived by making the divergence of the Navier-tokes equations. Numerical results of flows with free surfaces are presented to illustrate the effectiveness and robustness of the proposed upwind scheme.
\end{abstract}

Key wards: Third-order upwind scheme, Finite element method, Arbitrary Lagrangian-Eulerian method 3 次上流スキーム、有限要素法、ラグランジュ・オイラー混合法

\section{1.はじめに}

近年、造船、海洋工学などの分野において構造物周りの流 体現象の解明方様从な手法を用いて行われるようになった。 ここで対象上される流体注圧力による密度変化を無視するこ とができ、非理縮性流体と呼价れるもので、我々の身近に存 在する流れのほとんどがこの性質を仮定することができる。 また物体に働く抵抗を正しく評価するために、扱う流体特有 の粘性を考慮に入れなければならない。この流体注、非圧縮 性ナビェ・ストークス方程式と連続方程式によって支配され る。これらの方程式を数值的に解くことにより、ポテンシや ル理論では予測し得ない複雑な現象を解明することが可能と なる。

有限要素法では、SUPGスキーム、BTD 適用スキームなど 多くのスキームが使われてきたが、2 階微分で表される数値 粘性を付加した上流スキームで注、高レイノルズ数域におい て計算された解梳拡散的になることが知ら礼ている。これに 対して、3 次上流有限要素法 ${ }^{[1]}$ が有効であることが報告され ている。この手法は、摂動関数を標準重み関数の 2 階と 3 階
の空間微分の和で与えている。2階微分項は、移流項の離散 化にともなう 2 次の打ち切り誤差を消去する働きがある。こ の結果、移流項の離散化は 4 次精度の中心近似のものとなる。 3 階微分項は移流項と結びついて、4 階 3 次の数值粘性を作る 働きがあり、差分法で使われている 3 階 4 次のもの上同様な 性質走寸。これにより、高レイノルズ数域に扝ける数值的 発散が抑えられている。圧力の解法には、ナビェ・ストーク ス方程式の発散をとり、圧力のポアソン方程式を誘導し有限 要素近似を行う。これにより、圧力のポアソン方程式に適用 寸る形状関数に、流速と同じものを適用することができる。

自由表面を考慮寸る場合、ナビエ・ストークス方程式を直接 解き、自由表面の取り扱いが可能な方法として、Welch らによ り開発されたMAC(Marker-and-Cell) 法[2]が挙げられる。こ の方法法、時間進行と其に変化する自由表面形状を重さの無い 理想粒子により追跡寸る方法であり、多くの研究者により様从 な改良が進められている。主なものとしてAmsden、Haralaw によって解法が簡易化さた SMAC(Simplified MAC) 法 ${ }^{[3]}$ 功提 案された。宮田らはTUMMAC(Tokyo University Modified

\footnotetext{
*1 日本大学理厂学部 教授・辰博

*2 日本大学理工学部 慗任講的・正博

*3 日本大学理工学研究所 研究生 - 工博

Prof., Nihon Univ., College of Science and Technology, Dr. Eng. Assist., Prof., Nihon Univ., College of Science and Technology, Dr. Eng.

Researcher, Nihon Univ., Science and Technology Research Center, Dr. Eng.
} 
MAC) 法 ${ }^{[4]}$ を開発し、造船分野への応用を実施している。 オイラー的方法で染破など自由表面の大変形を伴う問題 も扱え、その用途の広さに利点がある。しかし、計算格子が固 定されており、自由表面位置を綮密に扱うことが出来ない。之 のため自由表面の数值的な扱いに近似が入ることが避けられな い。これに対し、自由表面に解析領域境界を適合させる、ラグ ランジュ的手法では、格子点を流体粒子と同一視するため、自 由表面を直接的に捉えることができる。しかし、ラグランジュ 的方法では、流体の運動に伴い要素の再分割が必要となる。こ のため格子点の移動量が大きくなった場合、有限要素のゆが 外に上り計算の続行が不可能になる場合がある。このラグラ ンジュ的方法の欠点を改善したものとして、ALE(Arbitarary Lagrangian-Eulerian) 法がある。この方法では、流体粒子の 速度と独立した格子移動の速度を導入し、計算格子の過度な 変形が抑えられている。また、計算格子の移動を自由表面近 傍にのみ施すことができ計算効率を高めることができる。

また有限要素法などを用いてナビェ・ストークス程式の 数值解析により、海洋構造物周りの流体現象を解明寸る場合、 無限に広がる海洋空間を任意の有限領域に限定しなければな らない。従って有限領域内に执いて波の反射等が数値解に及 ぼす影響を無く寸ためには、十分大きな有限領域を確保し、 その領域の中で数值計算を行うことになる。

本研究では、海洋空間に扔ける流体現象を解明するための 数值計算手法の確立を目的としている。その方法論として、 自由表面を有方る非圧縮粘性流体の数值解析に 3 次上流有限 要素法を用い、さらにALE法を採用した。また自由表面条件 に対方支支配方程式として運動学的条件式及び、応力の釣り 合い式を誘導し、運動学的条件式では波高を一価関数として 与えるように仮定玄る。

海洋空間のような自由表面問題を扱うための初段階として、 本論文では閉領域内で自由表面を有する問題へ本手法を適用 し、その有効性の確認を行うことを目的としている。具体的 な数値解析例として、2 次元孤立波反射問題、自由表面を有 する正方キャビティ内流れ問題をとりあげ、流れの様子を明 らかに打る。

\section{2. 基本式}

自由表面を有する非圧縮粘性流体を支配しているナビエ・ ストークス方程式と連続方程式は、無次元表示で以下のよう に与えられる。

$$
\begin{gathered}
u_{i, t}+u_{j} u_{i, j}=\sigma_{i j, j} \\
u_{i, i}=0
\end{gathered}
$$

ここで、 $u_{i}$ は流速、 $\sigma_{i j}$ は全応力、 ()$_{, t}=\partial / \partial t 、()_{, i}=\partial / \partial x_{i}$ である。また $t$ 以時間、 $x_{i}$ は座標変数を表卞。

全灾力 $\sigma_{i j}$ 蛙

$$
\sigma_{i j}=-P \delta_{i j}+\tau_{i j}
$$

で表され、動圧力 $P$ と粘性応力 $\tau_{i j}$ 梳、

$$
\begin{gathered}
P=p+\frac{x_{3}}{F n^{2}} \\
\tau_{i j}=\frac{1}{R e}\left(u_{i, j}+u_{j, i}\right)
\end{gathered}
$$

である。ここで、Fnはフルード数、Reはレイノルズ数、 $p$ は 圧力、 $\delta_{i j}$ はクロネッカー記号を示す。

一方、式(1)の発散を取ることにより、以下のような圧力の ポアソン力程式を得ることができる。

$$
P_{i i}=-\tilde{u}_{i, i}
$$

ここで、

$$
\tilde{u}_{i}=u_{i, t}+u_{j} u_{i, j}-\tau_{i j, j}
$$

である。また、自由表面にお汸る運動学的な条件式は、自由 表面を表す関数を $F$ とすれぱ、

$$
\frac{D F}{D t}=0
$$

と表すことが出来る。さらに $F$ 波高 $H$ によって、

$$
F=x_{3}-H
$$

と表示する。式(9)住、波高 $H$ を一価関数として表すことに なり、砕波を伴わないような自由表面を想定することになる。 これより、式(8) と式(9)加自由表面上の運動学的条件式は、

$$
H_{, t}+u_{\alpha} H_{, a}=u_{3}
$$

と表寺ここができる。ここで、添字杖1、2をとる。

以上の基本式を解くために、解析領域の境界は、流速境界 $\Gamma_{1}$ 、応力境界 $\Gamma_{2}$ 、自由表面境界 $\Gamma_{3}$ に分けられる。流速境界 $\Gamma_{1}$ では、

$$
u_{i}=\hat{u}_{i} \quad \text { on } \Gamma_{1}
$$

応力境界 $\Gamma_{2}$ では、

$$
\sigma_{i}=\sigma_{i j} n_{i}=\hat{\sigma}_{i} \quad \text { on } \Gamma_{2}
$$

が与えられ、 $\hat{u}_{i}$ と颌は各々規定值を示す。 $n_{i}$ 位単位法線ベク トルである。自由表面境界 $\Gamma_{3}$ では、自由表面の法線方向上接 線方向の力学的釣り合い式を考える。まず、法線方向の力学 的釣り合い式は、

$$
p-\tau_{i j} n_{i} n_{j}+T=p_{0}
$$

で表される。ここで、T梳面張力

$$
T=\gamma\left(\kappa_{1}+\kappa_{2}\right)
$$

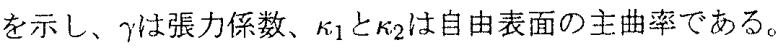
また $p_{0}$ は大気压を示卞。次に、接線方向の力学的釣り合い式 では、

$$
\tau_{i j} n_{i} s_{j}=0
$$


が与えられる。ここで、 $s_{j}$ は単位接線べクトルである。式(13)、 (15) は、自由表面上の境界条件として圧力のポアソン方程式 在解く際に適用される。

また $t=0$ に扔ける初期流速として以下の条件を付加寸る。

$$
u_{i}=\hat{u}_{i}^{0}
$$

ここで、 $\hat{u}_{i}^{0}$ は初期速度を示す。

\section{3 次上流有限要素スキ一ム}

非珐縮性ナビュ・ストークス方程式の適切な数值解を作る ために、上流化手法の一つである３次上流有限要素法を導入 する。

3 次上流スキーム梳、4 階 3 次の数值粘性を付加したスキー ムである。本論文では、ナビエ・ストークス方程式をペトロ フ・ガラーキン法に基づいた弱形式にする際、修正重み関数 を以下の上うに定義する。

$$
\bar{u}_{i}=w_{i}+\tilde{w}_{i}
$$

同様に式(10)に関する修正重子関数を以下のように定義する。

$$
\bar{H}=\theta+\tilde{\theta}
$$

ここで、 $w_{i} 、 \theta$ は標準重み関数で、 $\tilde{w}_{i} 、 \tilde{\theta}$ は摂動関数を表す。 物理現象を数值的に計算するとき、解の解像度を高めるた めに解析領域を不等メッシュに分割することが多い。しかし このような不等メッシュの下で直接に作られた有限要素方程 式仿、離散化に伴う打ち切り誤差により、高次精度を維持で きない。そこで精度を高めるために、有限要素法の場合でも 差分法と同じ上うに、写像空間の中で離散化を行うことが必 要になる。

物理空間 $\left(x_{i}, t\right)$ 加ら写像空間 $\left(\xi_{i}, \tau\right)$ 一以下のような座標 変換を行う。

$$
\xi_{i}=\xi_{i}\left(x_{1}, x_{2}, x_{3}, t\right), \quad \tau=t
$$

さらに上流化は対流項にだけ施す場合を考えて、式(1)は写 像空間内で次式のような弱表現として表すことができる。

$\int_{\bar{\Omega}} w_{i} u_{i / \tau} J d \bar{\Omega}+\int_{\bar{\Omega}}\left(w_{i}+\tilde{w}_{i}\right) U_{j} u_{i / j} J d \bar{\Omega}+\int_{\bar{\Omega}} \xi_{k, j} w_{i / k} \sigma_{i j} J d \bar{\Omega}$

$$
=\int_{\bar{\Gamma}} w_{i} \sigma_{i} I d \bar{\Gamma}
$$

同様に式(10)梳、以下のように表される。

$$
\int_{\bar{\Gamma}_{3}} \theta H_{/ \tau} I d \bar{\Gamma}+\int_{\bar{\Gamma}_{3}}(\theta+\tilde{\theta}) U_{\alpha} H_{/ \alpha} I d \bar{\Gamma}-\int_{\bar{\Gamma}_{3}} \theta u_{3} I d \bar{\Gamma}=0
$$

ここで、( $)_{/ \tau}=\partial / \partial \tau$ と ()$_{/ i}=\partial / \partial \xi_{i}$ は写像空閒内での偏微 分を表す。また、 $d \Omega=J d \bar{\Omega} 、 d \Gamma=I d \bar{\Gamma}$ を示し、 $J$ と $I$ は それぞれヤコビアンである。 $U_{i}$ 忙次式のように表される反変 流速である。

$$
U_{i}=\xi_{i, t}+\xi_{i, j} u_{j}
$$

次に、找動関数 $\tilde{w}_{i} 、 \tilde{\theta}$ 娄次のように定義寸る。

$\tilde{w}_{i}=-\frac{1}{3} \Delta \xi_{(j)}^{2} w_{i /(j j)}-\frac{1}{12} N_{D} \Delta \xi_{(j)}^{3} \operatorname{sgn}\left(U_{(j)}\right) w_{i /(j j j)}$

$\tilde{\theta}=-\frac{1}{3} \Delta \xi_{(\alpha)}^{2} \theta_{/(\alpha \alpha)}-\frac{1}{12} N_{D} \Delta \xi_{(\alpha)}^{3} \operatorname{sgn}\left(U_{(\alpha)}\right) \theta_{/(\alpha \alpha \alpha)}$

ここで、 $\Delta \xi_{i}$ は写像領域での要素の長さ、 $N_{D}$ は数值粘性の 強さを調整するパラメータである。またカッコ付き指標恀移 流項の指標 $j$ または $\alpha$ と同じ数值を取るものと定義する。上 式の右辺第 1 項注空間の微分作用素の離散化の精度を 4 次に 寸る働きがあり、右㳄第 2 項は、対流項を上流化する働きを 持つ。上記の摂動関数は標準重み関数の 2 階と 3 階の微分に より作られている。しかし、有限要素近似の際、線形形状関 数を使用するために、形状関数に一次式を用いて対流項につ いて高次精度の空間離散化を行う。そこで、以下のような補 助関数を採用する。

$$
\begin{gathered}
\omega_{i}=J U_{j} u_{i / j} \\
\phi_{i(j)}=\Delta \xi_{(j)}^{2} w_{i /(j j)} \\
\lambda=I U_{\alpha} H_{/ \alpha} \\
\psi_{(\alpha)}=\Delta \xi_{(\alpha)}^{2} \theta_{/(\alpha \alpha)}
\end{gathered}
$$

以上より、式(3)、(5)、(23)、(25)、(26) を用いると、式(20) は次式となる。

$$
\begin{gathered}
\int_{\bar{\Omega}} w_{i} u_{i / \tau} J d \bar{\Omega}+\int_{\bar{\Omega}}\left(w_{i} \omega_{i}-\frac{1}{3} J U_{j} \phi_{i(j)} u_{i / j}\right. \\
\left.-\frac{1}{12} N_{D} \Delta \xi_{(j)} J\left|U_{j}\right| \phi_{i(j) /(j)} u_{i / j}\right) d \bar{\Omega}
\end{gathered}
$$

$+\int_{\bar{\Omega}} \frac{1}{R e} \xi_{k, j} w_{i / k}\left(\xi_{n, j} u_{i / n}+\xi_{n, i} u_{j / n}\right) J d \bar{\Omega}-\int_{\bar{\Omega}} \xi_{j, i} w_{i / j} P J d \bar{\Omega}$

$$
=\int_{\bar{\Gamma}} w_{i} \sigma_{i} I d \bar{\Gamma}
$$

同様に、式(24)、(27)、(28) を使えば、式(21) は次式となる。

$$
\begin{gathered}
\int_{\bar{\Gamma}_{3}} \theta H_{/ \tau} I d \bar{\Gamma}+\int_{\bar{\Gamma}_{3}}\left(\theta \lambda-\frac{1}{3} I U_{\alpha} \psi_{(\alpha)} H_{/ \alpha}\right. \\
\left.-\frac{1}{12} N_{D} \Delta \xi_{(\alpha)} I\left|U_{\alpha}\right| \psi_{(\alpha) /(\alpha)} H_{/ \alpha}\right) d \bar{\Gamma} \\
-\int_{\bar{\Gamma}_{3}} \theta u_{3} I d \bar{\Gamma}=0
\end{gathered}
$$

補助関数式(25) 式(28)の重文付き残差方程式はそれぞれ以 下のようになる。

$$
\begin{gathered}
\int_{\bar{\Omega}} \bar{\omega}_{(i)} \omega_{i} d \bar{\Omega}=\int_{\bar{\Omega}} J U_{j} \bar{\omega}_{(i)} u_{i / j} d \bar{\Omega} \\
\int_{\bar{\Omega}} \bar{\phi}_{(i j)} \phi_{i(j)} d \bar{\Omega}=-\int_{\bar{\Omega}} \Delta \xi_{(j)}^{2} \bar{\phi}_{(i j) /(j)} w_{i /(j)} d \bar{\Omega} \\
+\int_{\bar{\Gamma}} \Delta \xi_{(j)}^{2} \bar{\phi}_{(i j)} w_{i /(j)} n_{(j)} d \bar{\Gamma} \\
\int_{\bar{\Gamma}_{3}} \bar{\lambda} \lambda d \bar{\Gamma}=\int_{\bar{\Gamma}_{3}} I U_{\alpha} \bar{\lambda} H_{/ \alpha} d \bar{\Gamma} \\
\int_{\bar{\Gamma}_{3}} \bar{\psi}_{(\alpha)} \psi_{(\alpha)} d \bar{\Gamma}=-\int_{\bar{\Gamma}_{3}} \Delta \xi_{(\alpha)}^{2} \bar{\psi}_{(\alpha) /(\alpha)} \theta_{/(\alpha)} d \bar{\Gamma}
\end{gathered}
$$




$$
+\int_{\bar{S}_{3}} \Delta \xi_{(\alpha)} \bar{\psi}_{(\alpha)} \theta_{/(\alpha)} n_{(\alpha)} d \bar{S}
$$

ここで、 $\bar{\omega}_{(i)} 、 \bar{\phi}_{(i j)} 、 \bar{\lambda} 、 \bar{\psi}_{\alpha}$ は標淮重み関数を表す。

次に、連続方程式(2)上压力のポアソン方程式(6)に関する 重み付き残差方程式は、 $q$ 上を $\vec{P}$ 重み関数として写像空間内で それぞれ以下の上うになる。

$$
\int_{\bar{\Omega}} \xi_{k, i} q u_{i / k} J d \bar{\Omega}=0
$$

$\int_{\bar{\Omega}} \xi_{k, i} \xi_{l, i} \bar{P}_{/ k} P_{/ l} J d \bar{\Omega}=\int_{\bar{\Omega}} \xi_{j, i} \bar{P} \tilde{u}_{i / j} J d \bar{\Omega}+\int_{\bar{\Gamma}} \xi_{l, i} \bar{P} P_{/ l} n_{i} I d \bar{\Gamma}$

以上が微分方程式系の弱表現である。これらは有限要素近 似によって離散系へ変換される。

\section{4. 有限要素方程式}

前章で示した各弱表現に対し、通常の線形要素を採用した 有限要素近似老行う。まず、式(29)、(31)、(32) は次の上う な離散方程式で表すことができる。

$$
\begin{gathered}
\mathbf{W}^{\dagger} \mathbf{M V}{ }_{/ \tau}+\mathbf{W}^{\mathrm{t}} \mathbf{B}_{1} \Omega-\Phi^{\mathrm{t}} \mathbf{A}_{3} \mathbf{V}-\Phi^{\mathrm{t}} \mathbf{A}_{4} \mathrm{~V}+\mathbf{W}^{\mathrm{t}} \mathbf{K V} \\
-\mathbf{W}^{\mathrm{t}} \mathbf{C P}=\mathbf{W}^{\mathrm{t}} \mathbf{F} \\
\mathrm{M}_{0} \boldsymbol{\Omega}=\mathbf{A}_{1} \mathbf{V} \\
\mathrm{M}_{0} \Phi=-\mathbf{B}_{2} \mathbf{W}
\end{gathered}
$$

同様に式(30)、(33)、(34)は以下のように表すことができ る。

$\boldsymbol{\Theta}^{\mathrm{t}} \overline{\mathbf{M H}}_{/ \tau}+\boldsymbol{\Theta}^{\mathrm{t}} \mathbf{D}_{\mathbf{1}} \boldsymbol{\Lambda}-\boldsymbol{\Psi}^{\mathrm{t}} \mathbf{E}_{3} \mathbf{H}-\boldsymbol{\Psi}^{\mathrm{t}} \mathbf{E}_{4} \mathbf{H}-\boldsymbol{\Theta}^{\mathrm{t}} \overline{\mathbf{M V}}_{3}=0 \quad(40)$

$$
\begin{gathered}
\overline{\mathbf{M}}_{0} \Lambda=\mathbf{E}_{1} \mathbf{H} \\
\overline{\mathbf{M}}_{0} \Psi=-\mathbf{D}_{2} \Theta
\end{gathered}
$$

ここで、 $\mathrm{V} 、 \mathrm{P} 、 \mathrm{~W} 、 \boldsymbol{\Omega} 、 \boldsymbol{\Phi} 、 \mathrm{H} 、 \Theta 、 \Lambda 、 \Psi 、 \mathrm{~V}_{3}$ は $u_{i} 、 P 、$ $w_{i} 、 \omega_{i} 、 \phi_{i j} 、 H 、 \theta 、 \lambda 、 \psi_{\alpha} 、 u_{3}$ に関寸る末知節点ベクトル、 F は外力のベクトル、他のものはそれぞれ行列を表す。式(38) と式(39) を式(37)八代入し、整理すると

$$
\mathrm{MV}_{/ \tau}+(\mathbf{N}+\mathbf{K}) \mathbf{V}-\mathbf{C P}=\mathbf{F}
$$

上なり、移流項の行列 $\mathbf{N}$ は以下の行列の計算によって与え られる。

$$
\mathbf{N}=\mathbf{B}_{1} \mathbf{M}_{0}^{-1} \mathbf{A}_{1}+\mathbf{B}_{2}^{\mathrm{t}} \mathbf{M}_{0}^{-\mathrm{t}} \mathbf{A}_{3}+\mathbf{B}_{2}^{\mathrm{t}} \mathbf{M}_{0}^{-\mathrm{t}} \mathbf{A}_{4}
$$

同様に、式(41) と式(42)を式(40)八代入し、整理すると

$$
\overline{\mathrm{MH}}_{/ \tau}+\overline{\mathrm{NH}}-\overline{\mathrm{M}} \mathrm{V}_{3}=0
$$

となり、移流項の行列 $\overline{\mathbf{N}}$ 以以下の行列の計算によって与え られる。

$$
\overline{\mathbf{N}}=\mathbf{D}_{1} \overline{\mathbf{M}}_{0}^{-1} \mathbf{E}_{1}+\mathbf{D}_{2}^{\mathrm{t}} \overline{\mathbf{M}}_{0}^{-\mathrm{t}} \mathbf{E}_{3}+\mathbf{D}_{2}^{\mathrm{t}} \overline{\mathbf{M}}_{0}^{-\mathrm{t}} \mathbf{E}_{4}
$$

上記行列 $\mathrm{N} 、 \overline{\mathrm{N}}$ の右辺第1 項と 2 項の和が移流項 $U_{j} u_{i / j}$ 、 $U_{a} h_{/ \alpha}$ に関与る 4 次精度の中心近似で、第 3 項が 4 階 3 次の 数值粘性項を表し、全体として上流化が計られる。式(35) と 式(36)の有限要素方程式は、それぞれ以下の上うに書くこ上 ができる。

$$
\begin{gathered}
\mathbf{R V}=\mathbf{0} \\
\mathbf{S P}=\mathbf{R} \tilde{\mathbf{V}}+\mathbf{G}
\end{gathered}
$$

ここで、 $\mathrm{S}$ と $\mathrm{R}$ 㹥行列、 $\mathrm{G}$ は压力の境界条件から得られる ベクトルである。

\section{5.計算手順}

以上から計算手順恃時間ステップを $n$ として以下の上うに する。

1. $n=0$ とおき $\mathbf{V}^{0} 、 \mathbf{H}^{0}$ に初期值を設定する。

2. 行列 $\mathrm{M} と \overline{\mathrm{N}}$ を作る。

3. $\mathbf{H}^{n+1}=\mathbf{H}^{n}+\Delta t\left(\mathbf{V}_{3}^{n}-\overline{\mathbf{M}}^{-1} \overline{\mathbf{N}} \mathbf{H}^{n}\right)$ を計算打る。

4. 自由表面の移動に伴う有限要素の再配置を行う。

5. 再配置後における節点座標べクトル及び流速ベクトルを 再配置前の各デー夕を用いて算出する。

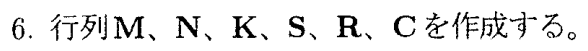

7. $\mathrm{V}^{n+\frac{1}{2}}=\mathrm{V}^{n}-\Delta t \mathbf{M}^{-1}\left(\mathrm{~N}^{n}+\mathrm{K}\right) \mathrm{V}^{n}$ の計算を行う。

8. $\mathbf{S} \mathbf{P}^{n+1}=-\frac{1}{\Delta t} \mathbf{R V}^{n+\frac{1}{2}}-\mathbf{R} \tilde{\mathbf{F}}^{n+1}+\mathbf{G}^{n+1}$ より $P^{n+1}$ を計 算する。 $\tilde{\mathbf{F}}^{n+1}$ は境界上の粘性力のベクトルを表す。

9. $\mathrm{V}^{n+1}=\mathrm{V}^{n+\frac{1}{2}}+\Delta t \mathbf{M}^{-1} \mathbf{C P}^{n+1}+\Delta t \mathbf{M}^{-1} \mathbf{F}^{n+1}$ の計算 走行う。

10. $n \leftarrow n+1$ に置き 2 )八戻り、必要な時閒まで繰り返し計 算子る。

\section{6. 数值解析例}

\section{6 . 1 . 孤立波反射問題}

\section{1 . 1 . 問題の設定}

この問題は計算スキームの検討に適しており、多くの研究

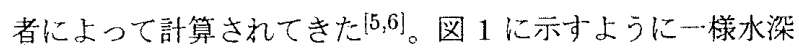
$h$ 、水路長 $2 l$ を持つ水槽の中央に孤立波を与えた。図 2 に 使用した有限要素メッシュの一部を示卞。また固定壁面上で、 滑り有りの条件を与えた。数值計算では、代表長 $L=h=1$ 、 代表流速 $V=\sqrt{g h} \cdot H_{0} / h$ に上り無次元化し、水路長 $l=8.0$ 、最大波高 $H_{0}$ と設定した場合について解析を行い、波の伝 播及び反射の過程を示古。初期条件として与える孤立波は、 Laitoneの近似式 $[7.8]$ を用い、以下のよ5に与えた。

$$
u_{1}=\operatorname{sech}^{2}\left[\left(\frac{3 H_{0}}{4}\right)^{\frac{1}{2}} x_{1}\right]
$$




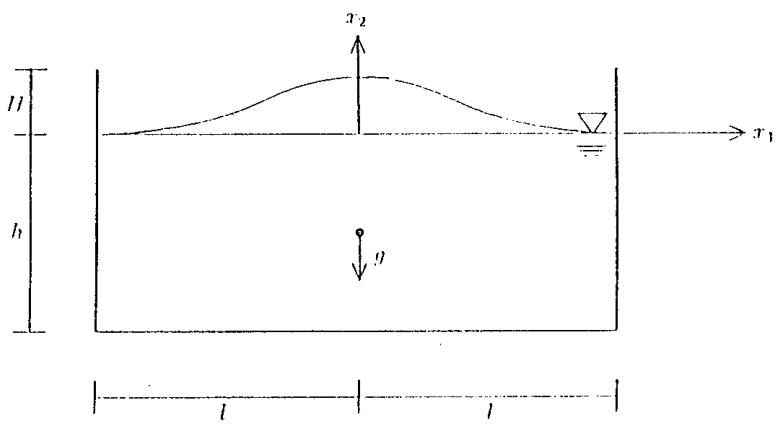

図 1: 問題の設定

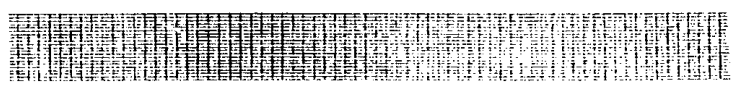

図 2: 有限要素メッシュ (一部)

$u_{2}=\sqrt{3}\left(H_{0}\right)^{\frac{1}{2}}\left(1+x_{3}\right) \operatorname{sech}^{2}\left[\left(\frac{3 H_{0}}{4}\right)^{\frac{1}{2}} x_{1}\right] \tanh ^{2}\left[\left(\frac{3 H_{0}}{4}\right)^{\frac{1}{2}} x_{1}\right]$

$$
H=H_{0} \operatorname{sech}^{2}\left[\left(\frac{3 H_{0}}{4}\right)^{\frac{1}{2}} x_{1}\right]
$$

この時のフルード数は、

$$
F n=\frac{V}{\sqrt{g L}}=H_{0}
$$

となり、レイノルズ数Reは、10 $10^{4}$ として与えた。

\subsection{2. 結果と考察}

図3〜16 は、初期の最大波高 $H_{0}=0.20$ 時の結果寺し

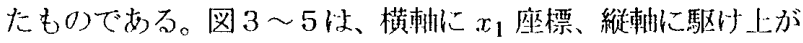
り高さ $R$ をとり、孤立波の伝播過程を示したものである。図 3に打いて初期状態から孟江波が右壁に駆り与がる様子が捉 えられている。また図4扔いて波が元の位置に戻った時、波 形、波高とも良く保持されている。図 5 以孤立波が中央から 左八移動し、左壁に駆け上がる様子を示したものである。

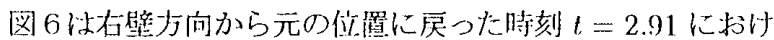
る波の状態である。図中のーダLaitoneに上万近似理諭解、O

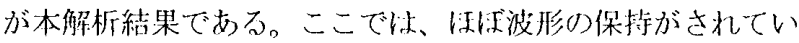
万が、固定壁近傍の水位士:昇量に差異が見られる。これは、粘 性の効果に上万减衰であると考えられる。図7〜16に領域

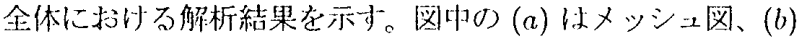
江流速ベクトル図、(c) 俚等压力線図定示寸。各時刻とも流劣 場は安定しており、压力の振動などは見られず苔定的に解析 が行むれてていることが分かる。ここで、眝刻 $t=1.455,4.365$

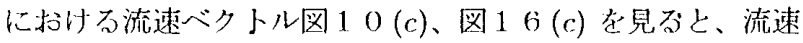
ベクトルがほとんど現れていない。これにより孤立波の進行

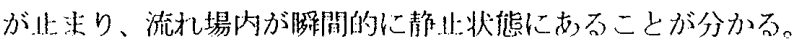
その後、波が这方问に進行していくという孤立波の反射のメ カニズムが度く招えられている。

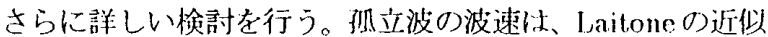

式より無次元表示で、

$$
c=\frac{\left(1+\frac{1}{2} H_{0}\right)}{H_{0}}
$$

と表寸ことができる。よって、波速の近似理羭㑇以(5.3)式上 り初期の最大波高 $H_{0}=0.2$ 老代入才礼ば $c=5.5$ と新算さ

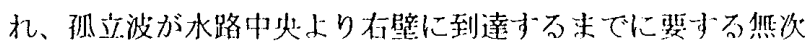

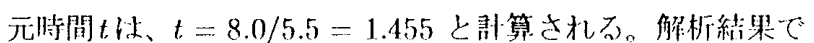
㑐、図 4 から $t=1.455$ の時に右譬八の駆け上がり高さが最

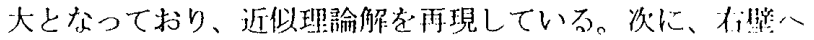
の駆け上がり高さについて㭘討を行う。同様にLaitoneの近 似式に上り、駆け上がり高さRは䦯次元表示で、

$$
R=2 H_{0}+\frac{1}{2}\left(H_{0}\right)^{2}
$$

となり、初期の最大波高 $H_{0}=0.2$ 艾代入正万と、 $R=0.42$

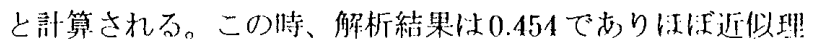
論解との一致が見られている。ただし、駆け上がり高さに睍

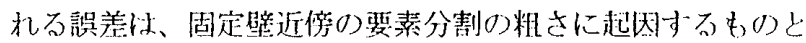
考えられる。生た、波が右壁に駆り上がり、再び元の位置に 戻った時 $H_{0}=0.2$ であった波高が 0.18 となっており、一制 汪どの減衰が見られた。これい小、粘性の效果に上万ものと考 えられる。

図1 7 以初期波高 $H_{0}$ 在変化させた時の孤汻波の不壁八の 駆け上がり高さR、を示したものである。图中のは（ａmficld ら [9]に上万実験值、○が本解析結果、一が近似理論解で女 万。これ小り本解析結果が、近似理論解よりも実験值に汪佂

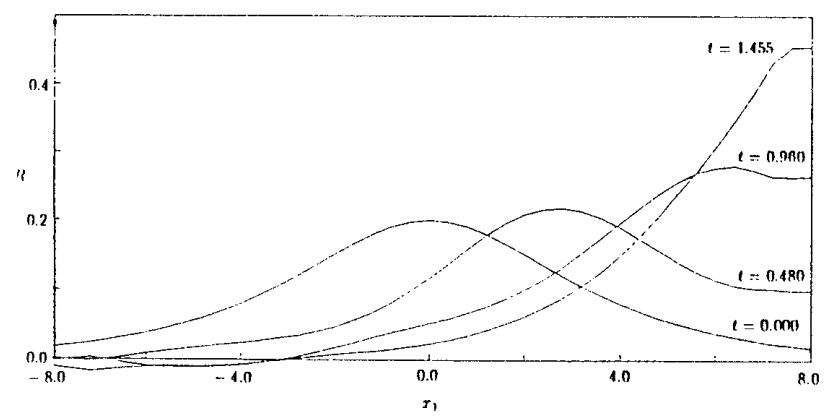

図3:㧓立波の伝播経過

$\left(t=0.0 \sim 1.455, R c=10^{4}, F n=0.2\right)$

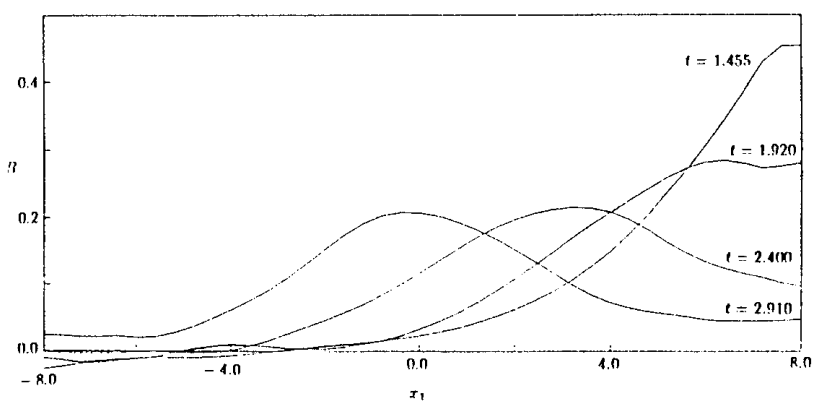

四4孤江波の伝播経過

$\left(t=1.455 \sim 2.910, R e=10^{4}, F n=0.2\right)$ 


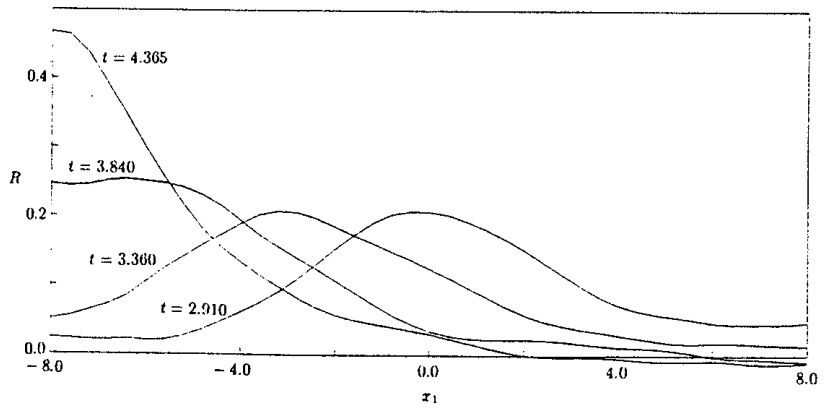

図 5 : 孤立波の伝播経過

$\left(t=2.910 \sim 4.265, R e=10^{4}, F n=0.2\right)$

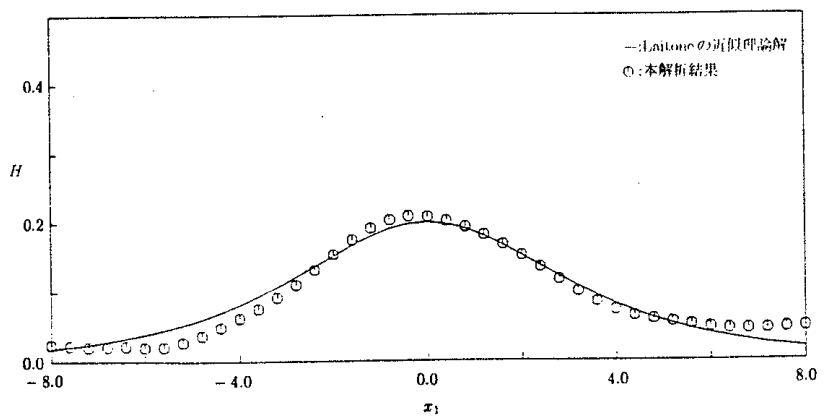

図 6: Laitoneの近似理論解との比較

$\left(t=2.910, R e=10^{4}, F n=0.2\right)$

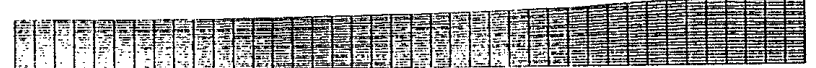

(a)メッシュ図

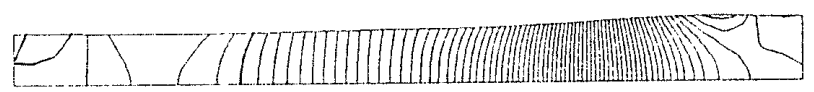

(b) 等圧力線図

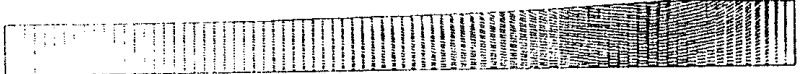

(c) 流速ベクトル図

図 9: 孤立波の解析結果 $\left(t=0.96, R e=10^{4}, F n=0.2\right)$

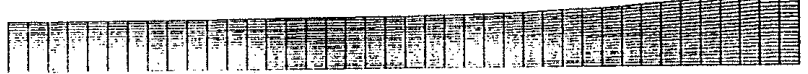

(a)メッシュ図

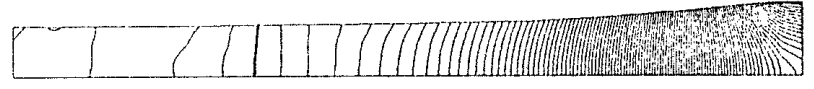

(b) 等圧力線図

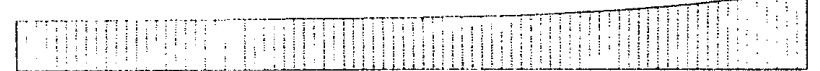

(c) 流速ベクトル図

図 $10:$ 孤立波の解析結果 $\left(t=1.455, R e=10^{4}, F n=0.2\right)$

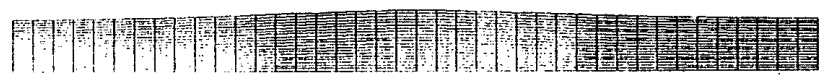

(a)メッシュ図

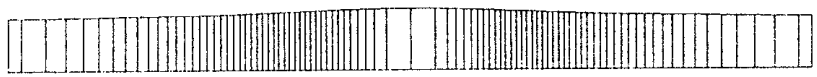

(b) 等圧力線図

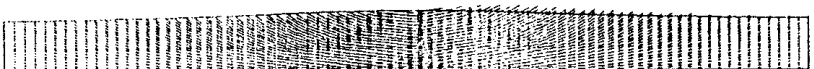

(c) 流速べクトル図

図 $7:$ 孤立波の解析結果 $\left(t=0.0, R e=10^{4}, F n=0.2\right)$ (a)メッシュ図

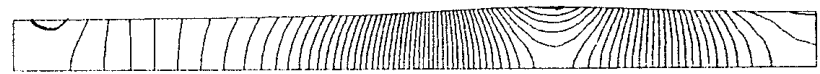

(b) 等圧力線図

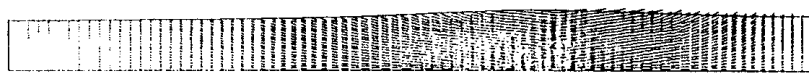

(c) 流速ベクトル図

図 8: 孤立波の解析結果 $\left(t=0.48, R e=10^{4}, F n=0.2\right)$

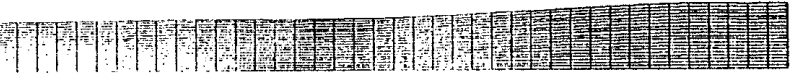

(a)メッシュ図

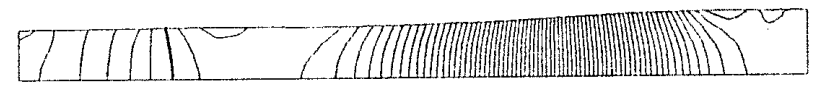

(b) 等压力線図

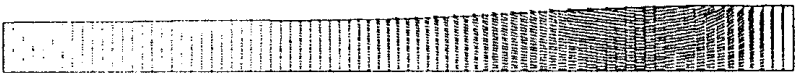

(c) 流速ベクトル図

図 11 : 孤立波の解析結果 $\left(t=1.92, R e=10^{4}, F n=0.2\right)$

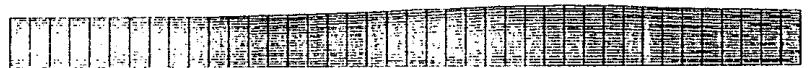

(a)メッシュ図

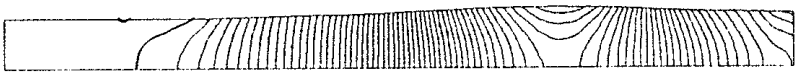

(b) 等圧力線図

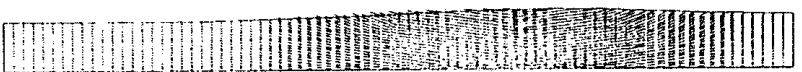

(c) 流速べクトル図

図 12 : 孤立波の解析結果 $\left(t=2.4, R e=10^{4}, F n=0.2\right)$ 


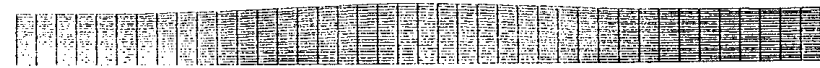

(a)メッシュ図

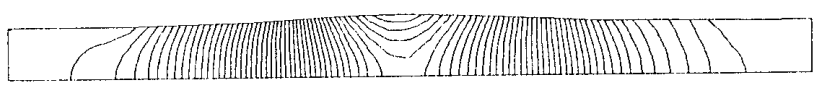

(b) 等圧力線図

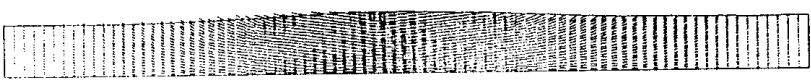

(c) 流速ベクトル図

図 13 : 孤立波の解析結果 $\left(t=2.91, R e=10^{4}, F n=0.2\right)$

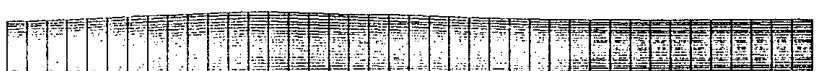

(a)メッシュ図

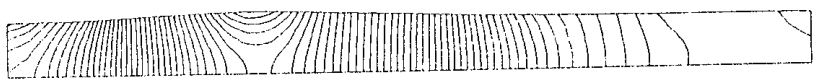

(b) 等压力線図

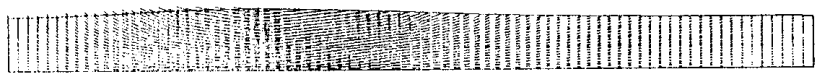

(c) 流速ベクトル図

図 14 : 孤立波の解析結果 $\left(t=2.91, R e=10^{4}, F n=0.2\right)$

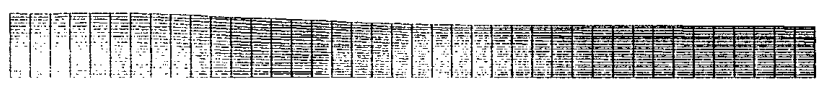

(a)メッシュ図

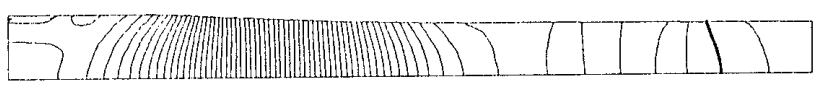

(b) 等圧力線図

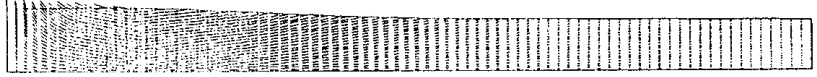

(c) 流速ベクトル図

図 15 : 孤立波の解析結果 $\left(t=3.84, R e=10^{4}, F n=0.2\right)$

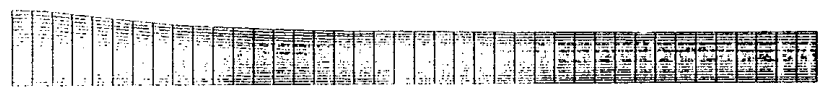

(a)メッシュ図

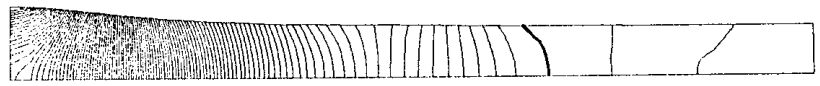

(b) 等圧力線図

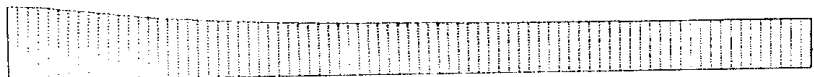

(c) 流速ベクトル図

図 16 : 孤立波の解析結果 $\left(t=4.365, R e=10^{4}, F n=0.2\right)$

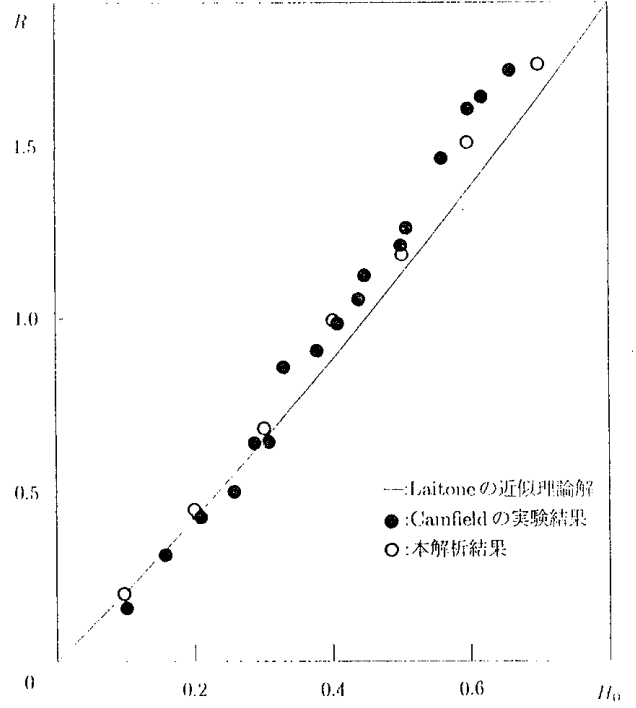

図 17 : 駆け上がり高さ $R$

一致していることがわかる。

これは、本解析が粘性を考慮に入れたため実現象に近い解 を示していると考えられる。

\section{2.正方キャビティ内流れ問題}

\subsection{1.問題の設定}

正方キャビティ流れ問題は、3つの壁を固定壁、残る壁を 一定速度により移動する壁とし、それにより駆動される流れ を対象とするもので、計算スキームの検証に適し、これまで に多くの研究者によって解析が行われてきた ${ }^{10,11]}$ 。しかし、 本論文では図 18 に示すようにキャビティの上壁を自由表面 とし下壁に一定流速を与えた場合の解析を行う。左右壁は滑 り有りの条件を設定した。この様な条件の下で、自由表面の 上下動の変化を捉える。図 19 に解析に用いた有限要素メッ シュを示寸。図のように境界層を精度良く評価するため、境 界壁近傍にメッシュを寄せた不等分割メッシュを用いた。本 解析では、代表長 $L=h=l$ 、レイノルズ数 $R e=400 、 フ$ ルード数 $F n=2.0 、$ 下壁に与える無次元流速を $\hat{u}=1.0$ 上 し解析を行った。

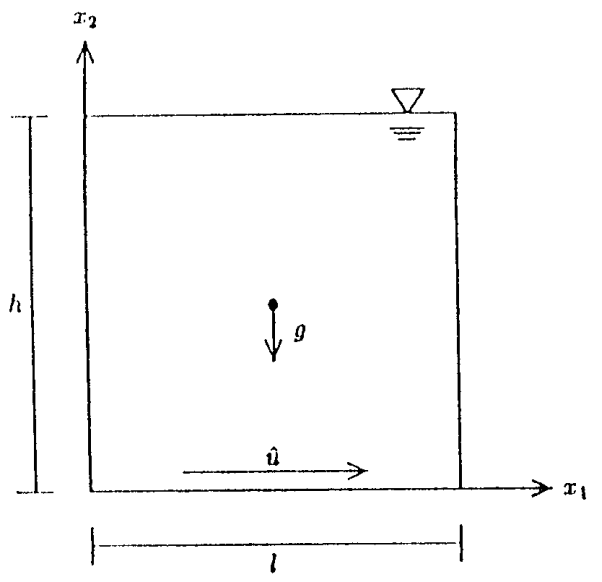

図 $18:$ 問題の設定 


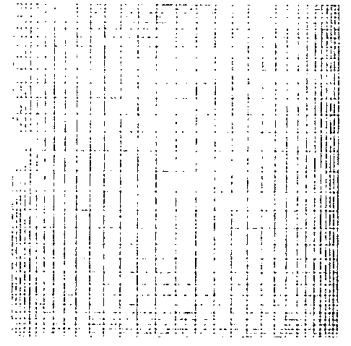

図 19 : 有限要素メッシュ

\subsection{2. 結果と考察}

図 20 ～ 21 に非定常状態における解析結果を示寸。 $(a)$ はメッシュ図、(b) 岄等圧力線図、(c) は流速ベクトル図をそ れぞれ示している。下壁の移動による右上部自由表面の上昇 が認められる。等圧力線図より、下方右隅の一次渦が形成さ れている位置で垝力の勾配が大きい。これ往来の自由表面 条件を考慮しない解析にも現れる現象である。本解析結果汇 圧力の振動も現れず妥当な解が得られ、自由表面条件の付加 による流れ場の特徴をよく捉えているといえる。

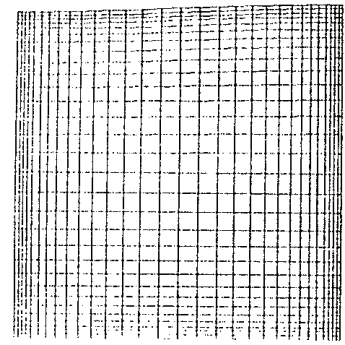

(a)メッシュ図

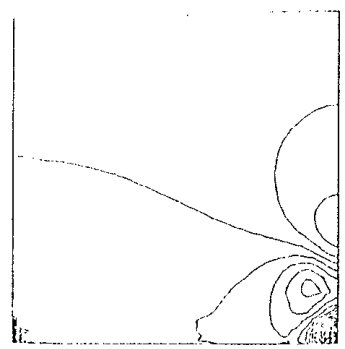

(b) 等圧力線図

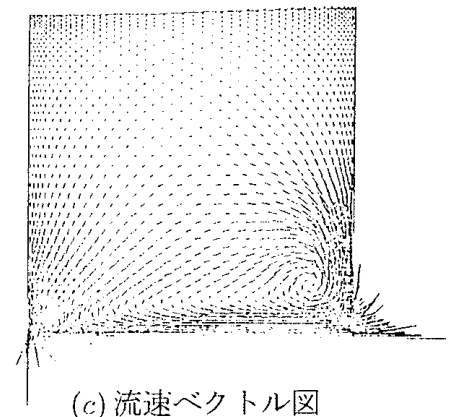

図 20: 正方キャビティの解析結果

$(t=1.0, R e=400, F n=2.0)$

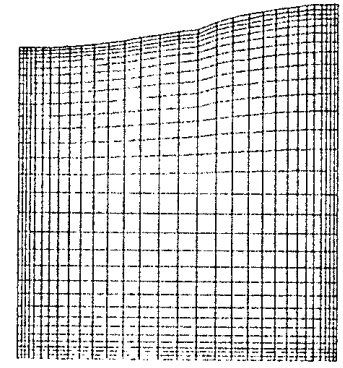

(a)メッシュ図

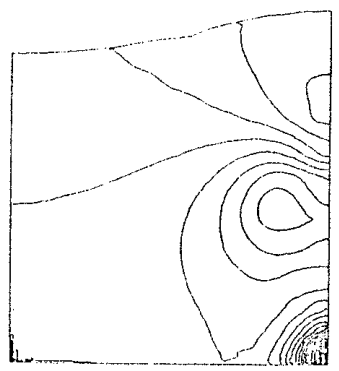

(b) 等圧力線図

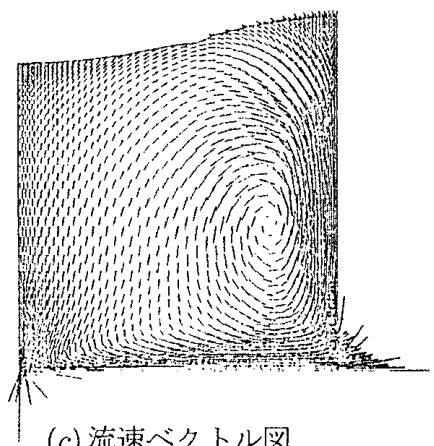

(c) 流速ベクトル図

図 21: 正方キャビティの解析結果

$(t=2.7, R e=400, F n=2.0)$

\section{7.おわりに}

自由表面を有する非圧縮性ナビエ・ストークス方程式の数 值解を安定に計算军るための3 次上流有限要素スキームを示 してきた。この上流スキームの中に組み込まれる数值粘性流 流速の 4 階微分で表現されており、ナビエ・ストークス方程式 の中の粘性とは直接比例しない。したがって、数值計算する 上で粘性を過大評価する事がなく、適切に数值計算を行うこ とができる。孤立波反射問題において本解析結果は、近似理 論解と実験結果に良く一致し、本手法が実現象を良くシミュ レートできることを示した。また、正方キャビテイ内流れ解 析では、自由表面の変化を安定的に捉えることができ、本手 法の有効性が示された。

\section{参考文献}

[1] N. Kondo, N. Tosaka and T. Nishimura, Numerical Simulation of Viscous Flows by the Third-Order Upwind Finite Element Method, Theoretical and Applied Mechanics, 39, 
University of Tokyo Press, 237-250, 1990.

[2] 武本行正, 武内智行, 奥村博司, 薦田広章, 自由表面および 内部境界面をもつ開水路非定常流の数值解析法, 農業土木学 会誌, 第 50 巻, 第6 号, 487-503, 1982年.

[3] A. A. Amsden and F. H. Harlow, A simplified MAC technique for incompressible fluid flow calculations, J. Comp. Phys., Vol.6, 322-325, 1970.

[4] H. Miyata, H. Kajitani, N. Suzuki and C. Matsukawa, Numerical and experimental analysis of nonlinear bow and stern waves of a two-dimensional body (First report ), J. Society Nav. Arch. of Japan, Vol.154, 1983.

[5] J. Fenton, A ninth-order solution for the solitary wave, J. Fluid Mech., Vol.53, 257-271, 1972.

[6] B. Ramaswamy, M. Kawahara, Arbitrary LagrangianEulerian finite element method for unsteady, convective, incompressible viscous free surface fluid flow, I. J. for Num. Methods in Fluids, Vol.7, 1053-1075, 1987.

[7] E. V. Laitone, The second approximation to cnoidal and solitary waves, J. Fluid Mech., Vol.9, 430-444, 1960.

[8] R. Grimshaw, The solitary wave of variable depth. Part 2, J. Fluid Mech., Vol.46, Part 3, 611-622, 1971.

[9] Camfield F. E. and R. L. Street, An investigation of the deformation and breaking of solitary waves, Dept. of Civil Engineering Technical Report, 81, Stanford Univ., 1967.

|10| M. Nallasamy and K. K. Prasad, On cavity flow at high Reynolds numbers, J. Fluid Mech., Vol.79, part2, 391-414, 1977.

[11] U. Ghia, K. N. Ghia and C. T. Shin, High-Re solutions for incompressible flow using the Navier-Stokes equation and a multigrid method, J. of Comp. Physics., 48, 387-411, 1982. [12] 岩津玲磨, 立在民, 桑原邦郎, 自由表面のあるキャビティ 内の流れ，第 5 海数值流体力学シンポジウム講演論文集, 373376,1991 年.

[13| N. Kondo, N. Tosaka and T. Nishimura, Computation of incompressible viscous flows by the third-order upwind finite element method, Internat. J. Numer. Meths. Fluids, Vol.15, 1013-1024, 1992.

[14] N. Kondo, N. Tosaka and T. Nishimura, Third-order upwind finite element formulations for incompressible viscous flow problems, Comput. Meths. Appl. Mech. Engrg., Vol.93, 169-187, 1993.
[15] P. B. Leonard, A survey of finite differences with upwinding for numerical modeliling of the incompressible convective diffusion equation, AIAA-paper, AIAA-84-0340, Vol.19.

[16] J. Donea, S. Giuliani, H. Laval and L. Quartapelle, Finite element solution of the unsteady Navier-Stokes equations by a fractional step method, Comput. Methods Appl. Mech. Eng., 30, 53-73, 1982.

[17] 武本行正, 田中雅史, 中村佳朗, 自由表面をもつTrench 内 流れと水中減勢工流れの数值解析, 第 4 回数值流体力学シン ポジウム講演論文集, 1990 年.

[18] 武本行正, 田中雅史, 中村佳郎, 一般化座標 Staggered Grid 系での自由境界問題解析について, 第 6 回数值流体力学シン ポジウム講演論文集, 381-384, 1992 年.

[19] 滰沢昭彦, 近藤駿介, 物理成分 BFC 法による自由液面の 解析, 第 4 回数値流体力学シンポジウム講演論文集, 553-556, 1990 年

$[20]$ 三輪俊彦, 川原睦人, 波の挙動に関古万非定常有限要素解 析, 第 4 回流れの有限要素解析シンポジウム論文集, 129-136, 1983 年.

[21] 高木周, 松本洋一郎, 反変速度による 3 次元自由表面流れ の数值計算手法, 第 7 回数值流体力学シンポジウム講演論文 集, 641-644, 1993年.

[22] 千葉賢, 桑原邦郎, 鉛直円柱回りの自由表面波の解析, 第 3 回数值流体力学シンポジウム講演論文集, 295-298, 1989 年. [23] 滝沢昭彦, 近藤駿介, 容器内自由液面流力援動発生条件, 第 6 回数值流体力学シンポジウム講演論文集, 399-402, 1992 年.

[24] 秋元博路, 杉原正記, 宮田秀明, 波の中を進行手る水平円 柱の渦運動と流体力, 日本造船学会論文集, 第 170 号, 253-263, 1993 年.

[25] B. Ramaswany, 川原睦人, ラグランジュ・オイラー混合 型有限要素法による自由表面問題の解析, 第 7 回流体力学に おける数值解析法シンポジウム講演論文集, 275-282, 1986 年. [26] 秋本博路, 宮田秀明, 朱明, 移動境界問題のシミュレー ション, 第 6 回数值流体力学シンポジウム講演論文集, 385388,1992 年.

[27] 近藤典夫, 西村敏雄, 加納充浩, 非圧縮粘性流れの3 次上 流有限要素シミュレーション, 日本建築学会構造系論文集, 第 458 号, 153-161, 1994年.

[28] 西村敏雄, テンソルとシェル理論, 彰国社, 1977 年. 